\title{
RASIO-RASIO KEUANGAN YANG BERPENGARUH TERHADAP NON PERFORMING LOAN (NPL) (Studi Bank Umum Konvensional Periode 2016-2018 di BEI)
}

\author{
Shandy Marsono ${ }^{1)}$, Irwan Christanto Edy ${ }^{2)}$ \\ ${ }^{1)}$ Program Studi : Akuntansi, STIE Adi Unggul Bhirawa Surakarta \\ ${ }^{2)}$ Program Studi : Akuntansi, STIE Adi Unggul Bhirawa Surakarta \\ Email : irwan.christanto@stie-aub.ac.id
}

\begin{abstract}
ABSTRAK
Penelitian ini bertujuan untuk mengetahui rasio-rasio keuangan yang meliputi Return On Assets (ROA), Loan To Deposit Ratio (LDR), Biaya Operasional per Pendapatan Operasional (BOPO), Net Interest Margin (NIM) dan Capital Adequacy Ratio (CAR) Terhadap Non Performing Loan (NPL) pada Bank Umum Konvensional yang Go Publicyang terdaftar di Bursa Efek Indonesia tahun 20162018. Penelitian ini merupakan penelitian deskriktif kuantitatif. Jenis data yang digunakan adalah data sekunder yang diperoleh dari www.bi.go.id dan www.Idx.co.id. berupa laporan keuangan tahunan bank yang digunakan sebagai sampel dengan periode waktu 3 tahun. Sedangkan sampel penelitian ini menggunakan metode purposive sampling dengan kriteria tertentu sehingga diperoleh sampel sebanyak 14 Bank.Berdasarkan metode analisis yang digunakan yakni regresi linier berganda yang telah lolos uji asumsi klasik dan uji hipotesis, diperoleh hasil bahwa secara parsial Return On Assets (ROA) berpengaruh negatif signifikan, Loan To Deposit Ratio (LDR), Biaya Operasional per Pendapatan Operasional (BOPO), dan Capital Adequacy Ratio (CAR) berpengaruh negatif tidak signifikan danNet Interest Margin (NIM) berpengaruh positif tidak signifikan terhadap Non Performing Loan (NPL). Dari hasil analisis nilai koefisien determinasi sebesar 0,240 atau 24\%. Hal ini berarti variabel ROA, LDR, BOPO, NIM dan CAR mempengaruhi variabel NPL sebesar 24\%, sedangkan sisanya dipengaruhi oleh variabel lain diluar penelitian ini.
\end{abstract}

Kata kunci : NPL, ROA, LDR, BOPO, NIM, CAR

\begin{abstract}
This study aims to determine financial ratios which include Return On Assets (ROA), Loan To Deposit Ratio (LDR), Operational Costs per Operating Income (BOPO), Net Interest Margin (NIM) and Capital Adequacy Ratio (CAR) against Non Performing Loans (NPL) at Conventional Commercial Banks that are Go Public which are listed on the Indonesia Stock Exchange in 2016-2018. This research is a quantitative descriptive study. The type of data used is secondary data obtained from www.bi.go.id and www.Idx.co.id. in the form of bank annual financial statements used as a sample with a time period of 3 years. While the sample of this study used purposive sampling method with certain criteria in order to obtain a sample of 14 banks. Based on the analysis method used, namely multiple linear regression which has passed the classical assumption test and hypothesis testing, the result is that partially Return on Assets (ROA) has a negative effect. significant, Loan To Deposit Ratio (LDR), Operational Costs per Operating Income (BOPO), and Capital Adequacy Ratio (CAR) have a negative and insignificant effect and Net Interest Margin (NIM) has a positive and insignificant effect on Non-Performing Loans (NPL). From the results of the analysis, the coefficient of determination is 0.240 or $24 \%$. This means that the variables ROA, LDR, OEOI, NIM and CAR affect the NPL variable by $24 \%$, while the rest is influenced by other variables outside of this study.
\end{abstract}

Keywords: NPL, ROA, LDR, BOPO, NIM, CAR 


\section{Pendahuluan}

Sumber utama pendapatan Bank Umum Konvensional berasal dari kredit dan pendanaan terhadap kerugian akibat dari risiko yang mungkin muncul karena penyaluran kredit harus ditanggung sendiri, tidak melibatkan nasabah dalam menanggung risiko kredit, bank hanya menerapkan sistem bunga sehingga membuat Bank Umum Konvensional lebih rentan terkena kredit bermasalah [1]. Setiap kredit yang diberikan tidak lepas dari berbagai risiko yang dapat mengancam kesehatan bank. Non Performing Loan (NPL) merupakan ukuran risiko kredit yang menjadi parameter tingkat kesehatan bank [2]. Bank dinilai memiliki potensi kesulitan yang membahayakan kelangsungan usahanya jika rasio kredit bermasalah (NPL) secara neto lebih dari 5\% dari total kredit (PBI/15/2/PBI/2013). Semakin besar tingkat NPL maka bank tersebut tidak profesional dalam pengelolaan kreditnya, sekaligus memberikan indikasi bahwa tingkat risiko atas pemberian kredit pada bank tersebut cukup tinggi searah dengan tingginya NPL [2]. Permasalahan dalam penelitian ini adalah mengetahui apakah rasio-rasio keuangan yang meliputi Return On Assets (ROA), Loan To Deposit Ratio (LDR), Biaya Operasional per Pendapatan Operasional (BOPO), Net Interest Margin (NIM) dan Capital Adequacy Ratio (CAR) berpengaruh signifikan terhadap Non Performing Loan (NPL).

\section{Landasan Teori dan Pengembangan HIpotesis}

Dalam mengukur tingkat efisiensi pengelolaan asset di bank diperlukan Return On Assets (ROA) yaitu perbandingan antara laba bersih dengan total aset bank. ROA suatu bank semakin besar maka semakin besar pula tingkat keuntungan (laba) bank tersebut dan posisi bank juga semakin baik dari segi penggunaan aset [4]. Menurut Surat Edaran Bank Indonesia NO.6.23/DPNP.2004 rumus untuk mengukur ROA adalah :

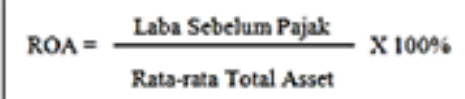

Ratio antara seluruh jumlah kredit yang diberikan bank dengan dana yang diterima oleh bank disebut Loan To Deposit Ratio (LDR) [5] . Rasio LDR yang paling sehat menurut Bank Indonesia paling tinggi adalah 94,75\%. LDR yang semakin tinggi maka NPL nya juga akan semakin tinggi. Menurut surat Edaran Bank Indonesia NO.6/23/DPNP.2004 rumus LDR adalah:

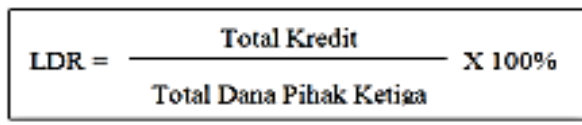

Rasio antara biaya operasional terhadap pendapatan operasional disebut Biaya Operasional per Pendapatan Operasional (BOPO) [5]. BOPO yang semakin kecil menunjukkan biaya operasional yang dikeluarkan bank semakin efisien, karena pendapatan operasional yang didapat semakin besar berbanding biaya operasional yang dikeluarkan yang berarti bank mendapat keuntungan yang semakin besar. Suatu bank dalam kondisi bermasalah biasanya salah satunya karena kredit bermasalah (NPL) semakin kecil [6]. Bank Indonesia menetapkan angka terbaik untuk rasio BOPO adalah dibawah 93,52\%. Menurut surat Edaran Bank Indonesia NO.6/23/DPNP.2004 rumus BOPO adalah: 


BOPO $=\frac{\text { Total Beban Operasional }}{\text { Total Pendapatan Operasional }} \times 100 \%$

Kemampuan bank dalam memperoleh pendapatan operasionalnya memalui kredit disebut Net Interest Margin (NIM). NIM yang semakin tinggi menunjukkan bank semakin efektif dalam penempatan aktiva produktif dalam bentuk kredit, sebaliknya ketika NIM menunjukkan persentase yang minim, maka akan terjadi kecenderungan munculnya kredit macet. Adapun Standar yang ditetapkan Bank Indonesia untuk rasio NIM adalah 6\% keatas. NIM dirumuskan dengan :

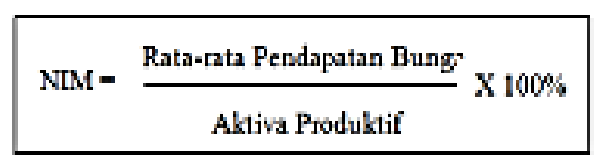

Perbandingan antara modal yang dimiliki dengan Aktiva Tertimbang menurut Risiko (ATMR) disebut Capital Adequacy Ratio (CAR), digunakan untuk memperlihatkan kecukupan modal yang dimiliki oleh suatu bank. CAR yang semakin tinggi, maka kemampuan bank dalam meminimalisir risiko kredit yang terjadi akan semakin besar. Hal ini berarti CAR yang semakin tinggi maka NPL bank akan semakin kecil [5]. Bank yang dinyatakan termasuk sebagai bank yang sehat harus memiliki CAR minimal sebesar $8 \%$. CAR dirumuskan dengan :

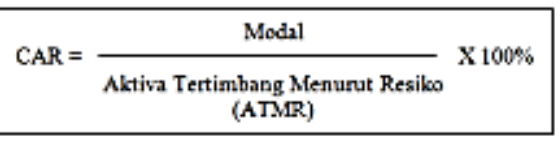

Kerangka Pemikiran Teoritis Pengaruh Variabel CAR, LDR, BOPO, NIM dan ROA terhadap NPL dalam penelitian ini dapat disajikan pada gambar 1 berikut :

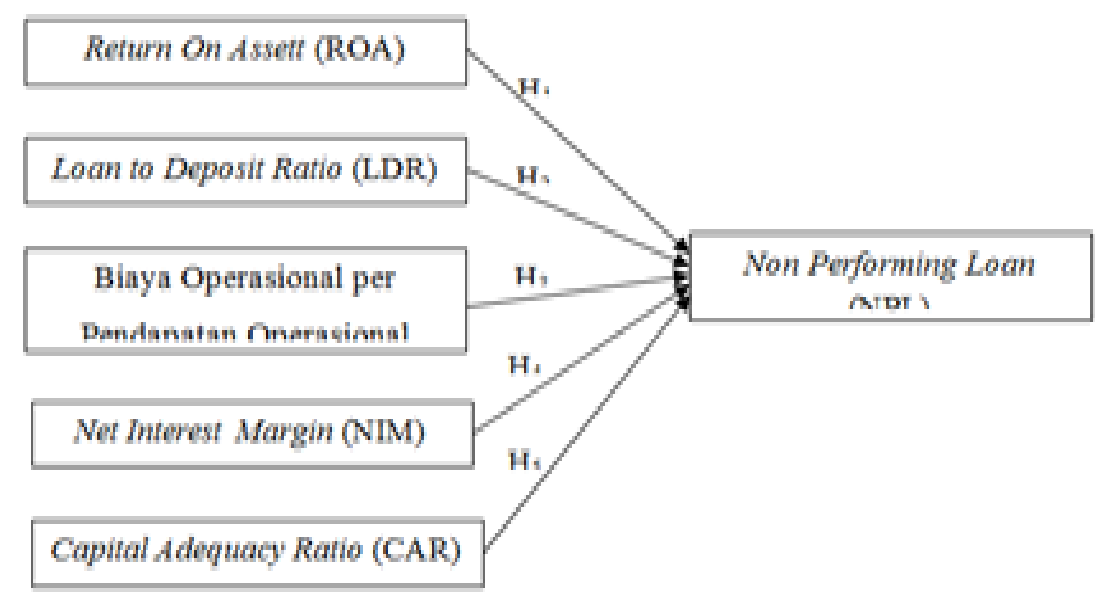

Gambar 1. Kerangka Konseptual Penelitian

Sumber : [2], [4], [5], [6]

\section{Metode Penelitian}

Penelitian ini merupakan Deskriktif Kuantitatif dengan Jenis data yang digunakan adalah data sekunder. Populasi yang digunakan dalam penelitian ini adalah bank umum konvensiona yang telah go public di Indonesia dalam kurun waktu 2016-2018. Jumlah bank umum konvensional di Indonesia yang telah go public sampai dengan tahun 2018 sebanyak 42 bank. 
Sedangkan metode yang digunakan dalam penelitian ini dalam pengambilan sampel adalah metode purposive sampling, sehingga diperoleh sampel sebanyak 14 bank. Teknik analisis dalam penelitian ini adalah: uji asumsi klasik, analisis regresi linier berganda, uji t, dan uji $\mathrm{R}^{2}$.

\section{Hasil dan Pembahasan}

Dari hasil analisis diperoleh output penelitian sebagai berikut:

\subsection{Uji Asumsi Klasik}

\section{a. Uji Normalitas}

Tabel 4.1. Hasil Uji Normalitas

\begin{tabular}{|c|c|c|c|c|c|c|c|}
\hline \multicolumn{8}{|c|}{ One-Sample Kolmogorov-Smirnov Test } \\
\hline & & ROA & LDR & BOPO & NIM & CAR & NPL NET \\
\hline Normal Parametersa,b & Mean & 2,0581 & 85,1552 & 81,3110 & 5,7948 & 19,0631 &,- 3214 \\
\hline & Std. Deviation & ,95420 & 10,17325 & 9,44610 & 2,20407 & 3,61583 & ,89093 \\
\hline $\begin{array}{l}\text { Most Extreme } \\
\text { Differences }\end{array}$ & $\begin{array}{l}\text { Absolute } \\
\text { Positive }\end{array}$ &, 188 &, 122 &, 160 & .184 &., 155 & ,091 \\
\hline & Negative & $\begin{array}{r}.188 \\
-138\end{array}$ & . & $\begin{array}{lll}, 120 \\
-, 160\end{array}$ & $\begin{array}{r}.184 \\
-110\end{array}$ & $\begin{array}{r}155 \\
-109\end{array}$ & .091 \\
\hline Kolmogorov-Smirnov $\mathrm{Z}$ & & 1,218 &, 791 & 1,040 & 1,193 & 1,002 & .592 \\
\hline Asymp. Sig. (2-tailed) & &, 103 & .560 & &, 116 & & 875 \\
\hline
\end{tabular}

b. Calculated from data.

Berdasarkan tabel 4.1 uji normalitas menggunakan uji Kolmogorov Smirnov, seluruh variabel menunjukkan bahwa nilai Asymp. Sig (2-Tailed) lebih besar dari 0,05. Hal ini menunjukan bahwa data berdistribusi normal.

b. Uji Multikolinieritas

Tabel 4.2. Hasil Uji Multikolinieritas

\begin{tabular}{|c|c|c|c|c|c|c|c|c|}
\hline \multicolumn{9}{|c|}{ Coefficients $^{\mathrm{a}}$} \\
\hline \multirow[b]{2}{*}{ Mod } & & \multicolumn{2}{|c|}{$\begin{array}{c}\text { Unstandardized } \\
\text { Coefficients }\end{array}$} & \multirow{2}{*}{$\begin{array}{c}\text { Standardized } \\
\text { Coefficients }\end{array}$} & \multirow[b]{2}{*}{$t$} & \multirow[b]{2}{*}{ Sig. } & \multicolumn{2}{|c|}{ Collinearity Statistics } \\
\hline & & B & Std. Error & & & & Tolerance & VIF \\
\hline \multirow[t]{6}{*}{1} & (Constant) & 4,582 & 3,154 & & 1,453 &, 155 & & \\
\hline & ROA &,- 696 & ,308 &,- 810 & $-2,258$ & ,030 & 148 & 6,766 \\
\hline & LDR &,- 009 & ,012 &,- 106 &,- 714 & 480 & 859 & 1,164 \\
\hline & BOPO &,- 015 & ,029 &,- 169 &,- 502 & 619 & 167 & 5,991 \\
\hline & NIM & ,116 & ,067 &, 313 & 1,736 & 091 &, 586 & 1,707 \\
\hline & CAR &,- 046 & ,034 &,- 204 & $-1,368$ & 180 & ,857 & 1,167 \\
\hline
\end{tabular}

a. Dependent Variable: NPL NET

Tabel 4.2 hasil Uji Multikolinieritas dapat diketahui bahwa semua nilai Tolerance $>0,1$ dan $\mathrm{VIF}<10$ maka tidak terjadi Multikolinieritas.

\section{c. Uji Heteroskedastisitas}

Tabel 4.3. Hasil Uji Heteroskedastisitas

\begin{tabular}{|c|c|c|c|c|c|c|}
\hline \multicolumn{7}{|c|}{ Coefficients } \\
\hline \multirow{2}{*}{\multicolumn{2}{|c|}{ Model }} & \multicolumn{2}{|c|}{$\begin{array}{l}\text { Unstandardiz ed } \\
\text { Coefficients }\end{array}$} & \multirow{2}{*}{$\begin{array}{c}\text { Standardized } \\
\text { Coefficients } \\
\text { Beta }\end{array}$} & \multirow[b]{2}{*}{$t$} & \multirow[b]{2}{*}{ Sig. } \\
\hline & & B & Std. Error & & & \\
\hline 1 & (Cons tant) & 1,902 & 1,642 & & 1,158 &, 254 \\
\hline & ROA &,- 262 & ,153 &,- 542 & $-1,717$ &, 095 \\
\hline & LDR &,- 013 &, 007 &,- 254 & $-1,980$ &, 055 \\
\hline & BOPO & ,008 & , 014 &, 167 &, 568 &, 574 \\
\hline & NIM &, 044 & ,034 & ,205 & 1,293 & ,204 \\
\hline & CAR &,- 034 &, 017 &,- 261 & $-1,976$ &, 056 \\
\hline
\end{tabular}

Tabel 4.3 disimpulkan bahwa tidak ada ataupun variabel independen yang signifikan secara statistik mempengaruhi variabel dependen nilai absolute residual. Hasil ini terlihat dari probabilitas signifikasinya diatas tingkat kepercayaan 5\%. Jadi dapat disimpulakn bahwa model regresi tidak mengandung heteroskedastisitas 


\section{d. Uji Autokorelasi}

Tabel 4.4. Hasil Uji Autokorelasi

\begin{tabular}{|l|r|r|r|r|r|}
\multicolumn{7}{|c|}{ Model Summary } \\
\hline Model & R & R Square & $\begin{array}{r}\text { Adjusted } \\
\text { R Square }\end{array}$ & $\begin{array}{r}\text { Std. Error of } \\
\text { the Estimate }\end{array}$ & $\begin{array}{r}\text { Durbin- } \\
\text { Watson }\end{array}$ \\
\hline 1 &, $561^{\mathrm{a}}$ &, 315 &, 220 &, 72435 & 1,986 \\
\hline
\end{tabular}

a. Predictors: (Constant), CAR, ROA, LDR, NIM, BOPO

b. Dependent Variable: NPL NET

Berdasarkan tabel 4.4 dapat diketahui bahwa nilai DW sebesar 1,986 artinya nilai Durbin Watson berada diantara -2 sampai dengan 2, hal ini menunjukkan bahwa tidak terjadi autokorelasi.

\subsection{Analisis Regresi Linier Berganda}

Tabel 4.5. Hasil Uji Regresi Linier Berganda

\begin{tabular}{|c|c|c|c|c|c|c|c|c|}
\hline \multirow[b]{2}{*}{ Model } & & \multicolumn{2}{|c|}{$\begin{array}{l}\text { Unstandardized } \\
\text { Coefficients }\end{array}$} & \multirow{2}{*}{$\begin{array}{c}\text { Stand ardized } \\
\text { Coefficients } \\
\text { Beta }\end{array}$} & & \multirow[b]{2}{*}{ Sig. } & \multicolumn{2}{|c|}{ Collinearity Statistics } \\
\hline & & $\mathrm{B}$ & Std. Error & & & & Tolerance & VIF \\
\hline 1 & (Constant'. & 4,582 & 3,154 & & 1,453 & .155 & & \\
\hline & ROA & -.796 & .308 & -810 & $-2,258$ & .030 & 148 & 6,766 \\
\hline & LDR & -2109 & 012 & -106 & -2714 & .480 & 859 & 1,164 \\
\hline & BOPC & -215 & .029 & -169 & -.502 & .619 & .167 & 5,991 \\
\hline & NIM & .116 & .067 & .313 & 1,736 & 021 & .586 & 1,707 \\
\hline & CAR & -.076 & .034 & -204 & $-1,368$ & 180 & .857 & 1,167 \\
\hline
\end{tabular}

Berdasarkan tabel 5 diperoleh persamaan regresi linier berganda sebagai berikut :

NPL $=4,582-0,796 X_{1}-0,109 X_{2}-0,115 X_{3}+0,116 X_{4}-0,076 X_{5}$

Keterangan :

$\mathrm{Y}=\mathrm{NPL}$

$$
\begin{array}{ll}
\mathrm{X} 1 & =\mathrm{ROA} \\
\mathrm{X} 2 & =\mathrm{LDR} \\
\mathrm{X} 3 & =\mathrm{BOPO} \\
\mathrm{X} 4 & =\mathrm{NIM} \\
\mathrm{X} 5 & =\mathrm{CAR}
\end{array}
$$

Penjelasan dari persamaan regresi tersebut adalah sebagai berikut :

a. Nilai konstanta 4,582 menunjukkan nilai positif artinya jika variabel-variabel independen yaitu ROA, LDR, BOPO, NIM dan CAR diasumsikan konstan atau tetap maka NPL positif

b. Koefisien regresi $\beta 1$ sebesar $-0,796$ nilai negatif, ini menunjukan jika ROA meningkat maka NPL akan mengalami penurunan dengan asumsi bahwa variabel independen yang lain dianggap konstan

c. Koefisien regresi $\beta 2$ sebesar $-0,109$ nilai negatif artinya menunjukan bahwa jika LDR meningkat maka NPL akan menurun dengan asumsi bahwa variabel independen yang lain konstan

d. Koefisien $\beta 3$ sebesar $-0,115$ nilai negatif, menunjukkan bahwa jika BOPO meningkat maka NPL akan menurun dengan asumsi bahwa nilai variabel independen yang lain dianggap konstan 
e. Koefisien $\beta 4$ sebesar 0,116 nilai positif, menunjukkan bahwa jika NIM meningkat maka NPL akan meningkat dengan asumsi bahwa nilai variabel independen yang lain dianggap konstan

f. Koefisien $\beta 5$ sebesar $-0,076$ nilai negatif, menunjukkan bahwa jika CAR meningkat maka NPL menurun dengan asumsi bahwa nilai variabel independen yang lain dianggap konstan

\subsection{Uji t}

Tabel 4.6. Hasil Uji t

\begin{tabular}{|c|c|c|c|c|c|c|c|c|}
\hline \multicolumn{9}{|c|}{ Coefficients ${ }^{a}$} \\
\hline \multirow[b]{2}{*}{ Model } & & \multicolumn{2}{|c|}{$\begin{array}{l}\text { Unstandardiz ed } \\
\text { Coefficients }\end{array}$} & \multirow{2}{*}{$\begin{array}{c}\begin{array}{c}\text { Standardized } \\
\text { Coefficients }\end{array} \\
\text { Beta } \\
\end{array}$} & \multirow[b]{2}{*}{ t } & \multirow[b]{2}{*}{ Sig. } & \multicolumn{2}{|c|}{ Collinearity Statistics } \\
\hline & & $B$ & Std. Error & & & & Tolerance & VIF \\
\hline & (Cons tant) & 4,582 & 3,154 & & 1,453 &, 155 & & \\
\hline & ROA &,- 696 &, 308 &,- 810 & $-2,258$ &, 030 & , 148 & 6,766 \\
\hline & LDR &,- 009 & 012 &,- 106 &,- 714 & ,480 & 859 & 1,164 \\
\hline & BOPO & -,015 & ,029 & $\begin{array}{l}-, 169 \\
-, 169\end{array}$ &,- 502 & 619 &, 167 & 5,991 \\
\hline & NIM &, 116 &, 067 & ,313 & 1,736 & 091 & 586 & 1,707 \\
\hline & CAR & , 046 &, 034 & -,204 & $-1,368$ & , 180 & 857 & 1,167 \\
\hline
\end{tabular}

Hasil uji t dapat diketahui bahwa:

Tabel 4.7. Hasil Pengujian Hipotesis

\begin{tabular}{clccl}
\hline No & Hubungan Variabel & Prob.Sign & Kriteria & Kesimpulan Hipotesis \\
\hline 1 & ROA berpengaruh signifikan terhadap NPL & 0,030 & $0,030<0,05$ & Hipotesis 1 diterima \\
2 & LDR berpengaruh signifikan terhadap NPL & 0,480 & $0,480>0,05$ & Hipotesis 2 ditolak \\
3 & LDR berpengaruh signifikan terhadap NPL & 0,619 & $0,619>0,05$ & Hipotesis 3 ditolak \\
4 & LDR berpengaruh signifikan terhadap NPL & 0,910 & $0,910>0,05$ & Hipotesis 4 ditolak \\
5 & LDR berpengaruh signifikan terhadap NPL & 0,180 & $0,180>0,05$ & Hipotesis 5 ditolak \\
\hline
\end{tabular}

\subsection{Uji Koefisien Determinasi $\left(\mathbf{R}^{2}\right)$}

Tabel 4.6.Hasil Koefisien Determinasi $\left(\mathrm{R}^{2}\right)$

\begin{tabular}{|l|r|r|r|r|c|}
\hline Model & $\mathrm{R}$ & R Square & $\begin{array}{l}\text { Adjusted } \\
\text { R Square }\end{array}$ & $\begin{array}{l}\text { Std. Error of } \\
\text { the Estimate }\end{array}$ & $\begin{array}{l}\text { Durbin- } \\
\text { Watson }\end{array}$ \\
\hline 1 & 661 & 395 & 240 & .72435 & 1,986 \\
\hline
\end{tabular}

a. Predictors: (Constant), CAR, ROA, LDR, NIM, BOPO

b. Dependent Variable: NPL NET

Hasil uji Koefisien Determinasi $\left(\mathrm{R}^{2}\right)$ pada penelitian ini diperoleh nilai sebesar 0,240. Hal ini menunjukkan bahwa NPL dipengaruhi oleh ROA, LDR, BOPO, NIM dan CAR sebesar $24 \%$, sedangkan sisanya sebesar $76 \%$ dipengaruhi oleh faktor lain yang tidak diteliti dalam penelitian ini. Misalnya Suku Bunga, Inflasi, Kurs dan lain sebagainya.

\subsection{Pembahasan}

a. ROA berpengaruh negatif dan signifikan terhadap NPL, artinya jika ROA (tingkat profit/laba) mengalami kenaikan maka NPL (rasio kredit bermasalah) perbankan akan mengalami penurunan. Peningkatan tingkat keuntungan (laba) menggambarkan pengelolaan asset yang baik dan pengelolaan asset yang baik akan menurunkan rasio kredit bermasalah. Hal ini juga mengidentifikasi bahwa terjadinya peningkatan laba terhadap resiko kredit tidak semata-mata karena profitabilitas, artinya kredit bermasalah 
bukan hanya berasal dari ROA tetapi dari faktor lain. Hasil penelitian ini realitis mendukung teori meski tidak sepaham dengan hasil penelitian dari yang menyatakan bahwa ROA berpengaruh positif dan signifikan terhadap NPL [7]

b. LDR berpengaruh negatif dan tidak signifikan terhadap NPL artinya jika LDR mengalami kenaikan NPL perbankan akan mengalami penurunan. Hasil ini mengidentifikasikan bahwa perbankan telah memiliki sistem pengawasan yang cukup baik terutama dalam penilaian nasabah, sehingga yang mempengaruhi NPL bukan LDR nya tetapi lebih mengenai tindakan preventif terhadap kredit yang lebih ketat. Hal tersebut mendorong penurunan rasio kredit bermasalah Penelitian ini tidak sepaham dengan penelitian [8], [2], [9]

c. BOPO berpengaruh negatif dan tidak signifikan terhadap NPL artinya jika BOPO mengalami peningkatan maka NPL perbankan akan mengalami penurunan. Hal ini dikarenakan jumlah biaya operasional yang meningkat akan menurunkan pendapatan operasional bank, karena biaya operasional digunakan untuk pencegahan kredit bermasalah. Hasil ini tidak sepaham dengan penelitian terdahulu [9].

d. NIM berpengaruh positif dan tidak signifikan terhadap NPL, artinya jika NIM mengalami peningkatan maka NPL akan mengalami peningkatan. Hal ini disebabkan karena jumlah pendapatan bunga yang diterima oleh Bank meningkat. Peningkatan tersebut disebabkan karena landing rate atau suku bunga kredit meningkat sehingga resiko kreditnya juga semakin tinggi. Penelitian ini tidak sepaham dengan penelitian terdahulu [10]

e. CAR berpengaruh negatif dan tidak signifikan terhadap NPL, artinya jika CAR meningkat maka NPL akan turun. CAR digunakan untuk mengatasi atau menyikapi atas berbagai resiko investasi yang diantaranya adalah kredit. CAR disebabkan karena investasi yang berisiko, sehingga CAR tidak begitu berpengaruh terhadap NPL. Dengan keberhasilan investasi yang berisiko maka akan menambah CAR. Penelitian ini sesuai dengan penelitian terdahulu [1].

\section{Kesimpulan}

\subsection{Simpulan}

1. ROA berpengaruh negatif signifikan terhadap NPL.LDR berpengaruh negatif tidak signifikan terhadap NPL.BOPO berpengaruh negatif tidak signifikan terhadap NPL. NIM berpengaruh positif tidak signifikan terhadap NPL. CAR berpengaruh negatif tidak signifikan terhadap NPL.

2. Hasil uji Koefisien Determinasi $\left(\mathrm{R}^{2}\right)$ pada penelitian ini diperoleh nilai sebesar 0,220. Hal ini menunjukkan bahwa NPL dipengaruhi oleh ROA, LDR, BOPO, NIM dan CAR sebesar $24 \%$, sedangkan sisanya sebesar $76 \%$ dipengaruhi oleh faktor lain seperti suku bunga, inflasi, kurs, jangka waktu dan lain sebagainya. 


\subsection{Saran}

Adapun saran-saran yang dapat dikemukakan dalam penelitian ini untuk pihak-pihak yang berkepentingan dimasa yang akan datang demi pencapaian manfaat yang optimal dan pengembangan dari hasil penelitian berikut :

a. Penelitian selanjutnya diharapkan dapat memperbanyak jumlah sampel penelitian dimana tidak hanya Bank Umum Konvensional yang Go Public tetapi juga Bank Umum Swasta Devisa dan Syariah yang terdaftar di BEI.

b. Peneliti menyarankan agar penelitian dimasa mendatang mampu memperhatikan factor lain diluar non keuangan yang mungkin dapat mempengaruhi kredit bermasalah seperti Kurs, Tingkat Suka Bunga, Inflasi, Jangka Waktu dan indikator lain yang diharapkan mampu mewakili semua variabel yang mempengaruhi kredit bermasalah selain itu peneliti juga menyarakan untuk menambah jangka waktu penelitian sehingga diperoleh hasil lebih jelas.

c. Variabel ROA berpengaruh negatif dan signifikan terhadap NPL dalam hal ini peneliti menyarankan agar ROA ditingkatkan, salah satu cara untuk meningkatkan ROA adalah dengan meningkatkan margin yang tentunya harga diterima pasar atau dengan mengurangi biaya sehingga perusahaan dapat meningkatkan laba melalui asset.

\section{Daftar Pustaka}

[1] K. D. Jayanti, "Analisis Faktor-Faktor Yang Mempengaruhi Non-Performing Loan ( Studi Pada Bank Umum Konvensional Yang Go Public Di Indonesia Periode 2008-2012 )," Universitas Diponegoro, 2013.

[2] S. Riyadi, Banking Assets and Liability Management. Jakarta: BP. FE Universitas Indonesia, 2006.

[3] PBI/15/2/PBI/2013, "Penetapan Status Dan Tindak Lanjut Pengawasan Bank Umum Konvensional," 2013.

[4] G. W. Wardhana, "Analisis Faktor-Faktor Yang Mempengaruhi Non Performing Loan," Diponegoro J. Manag., vol. 4, pp. 1-11, 2015.

[5] L. Dendawijaya, Manajemen Perbankan. Jakarta: Ghalia Indonesia, 2009.

[6] F. Pandia, Manajemen Dana Dan Kesehatan Bank. Jakarta: PT Rineka Cipta, 2012.

[7] M. U. Achmadi, "Pengaruh Capital Adequacy Ratio, Rasio Biaya Operasi Atas Pendapatan Operasi, Return On Asset Terhadap Non Performance Loan Bank Nasional," Media Bisnis., vol. 6, no. 1, 2014.

[8] Arniati, T. Rohana, and E. Sinuhaji, "Pengaruh Loan to Deposit Ratio terhadap Non Performing Loan pada PT. Bank Sumut," J. Ilman, vol. 6, no. 1, 2018.

[9] S. Riyadi, M. Iqba, and N. Lauren, "Strategi pengelolaan Non Performing Loan Bank Umum Yang Go Public,” J. Din. Manaj., vol. 6, no. 1, pp. 84-96, 2015.

[10] J. S. P. Ginting and M. A. Haryanto, "Pengaruh Capital Adequacy Ratio, Loan to Deposit Ratio, Loan Loss Provision dan Net Interest Margin terhadap Non Performing Loan (Studi Kasus pada Bank Umum Konvensional di Indonesia yang terdaftar di BEI pada tahun 20082014)," DIPONEGORO J. Manag., vol. 5, no. 1, 2015. 